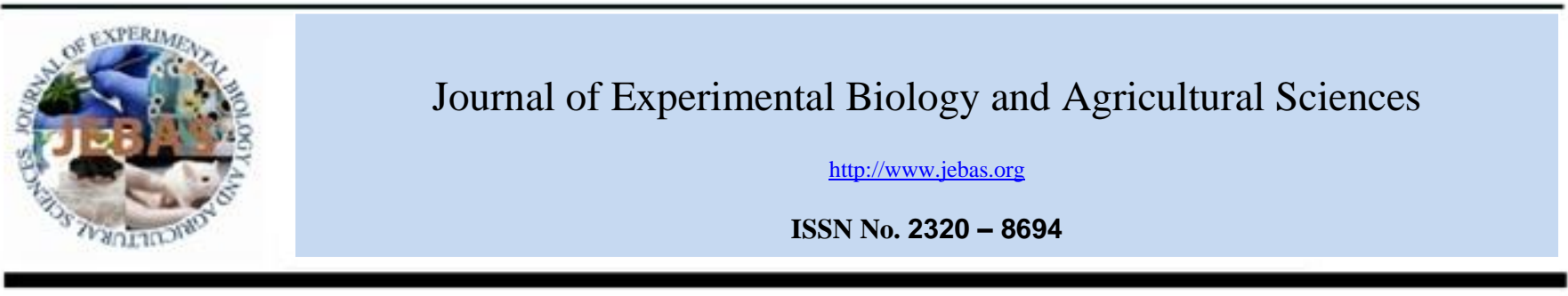

\title{
RESPONSE OF SOYBEAN (Glycine max) TO MOLYBDENUM AND IRON SPRAY UNDER WELL-WATERED AND WATER DEFICIT CONDITIONS
}

\author{
Ayoub Heidarzade ${ }^{1}$, Mohammadali Esmaeili ${ }^{1, *}$, Mohammadali Bahmanyar ${ }^{2}$ and Rahmat Abbasi ${ }^{1}$ \\ ${ }^{1}$ Department of Agronomy, Sari Agricultural Sciences and Natural Resources University, Sari, Iran \\ ${ }^{2}$ Department of Soil Sciences, Sari Agricultural Sciences and Natural Resources University, Sari, Iran \\ Received - December 16, 2015; Revision - December 29, 2015; Accepted - January 31, 2016 \\ Available Online - February 20, 2016
}

DOI: http://dx.doi.org/10.18006/2015.4(1).37.46

\begin{abstract}
KEYWORDS
Micronutrient

Soybean

Water deficit stress

Yield parameters

ABSTRACT

Effects of foliar application of molybdenum and iron either individually or in combination on the yield properties of soybean crop were investigated under water deficit condition at research farm of Sari Agricultural Sciences and Natural Resources University, Sari, Iran during the cropping season of 2014. This experiment was laid out in factorial arrangement based on completely randomized block design with three replications. The two irrigation regimes were used (Irrigation after 65 and $130 \mathrm{~mm}$ evaporation from Class A pan) as primary factors while spray application of micronutrient (water as control $\mathrm{Fe}, \mathrm{Mo}$ and $\mathrm{Fe}+\mathrm{Mo}$ ) were considered as the secondary factors. Result of study revealed that drought stress and micronutrient sprays have effect on all studied parameters such as pod number, seed number, yield and weight of 1000 seeds. Also, the interactions were statistically significant among studied parameters. According to the results drought stress severely impressed the number of pods, total seed numbers, seed yield, seed protein and seed oil. Furthermore, using of micronutrients spray particularly Fe+Mo on soybean crop is environmentally acceptable strategy and reduced the damages caused by water deficit condition.
\end{abstract}

* Corresponding author

E-mail: esmaeili33@gmail.com (Mohammadali Esmaeili)

Peer review under responsibility of Journal of Experimental Biology and Agricultural Sciences.

Production and Hosting by Horizon Publisher (http://publisher.jebas.org/index.html).

All rights reserved.
All the article published by Journal of Experimental Biology and Agricultural Sciences is licensed under a Creative Commons Attribution-NonCommercial 4.0 International License Based on a work at www.jebas.org.

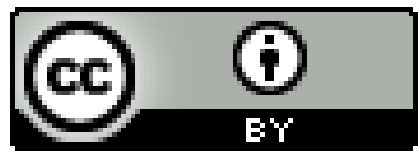




\section{Introduction}

Soybean (Glycine max) is a common legume plant and cultivated for more than 3000 years in Southeastern Asia (Dwevedi \& Kayastha, 2011). Soybean stands first in the world as edible oil and occupies important place in the economy. Climatic and edaphic factors severely affect its production; according to Turner (1991) performance of this crop is highly affected by the availability of trace elements such as Molybdenum and Iron. It has been also well reported that deficiency of micronutrients such as $\mathrm{Fe}, \mathrm{Mn}$ and $\mathrm{Zn}$ affect the soybean production (Khudsar et al., 2008; Caliskan et al., 2008).

Furthermore, various researcher reported that the application of essential micronutrients such as Zinc, Iron and Magnesium improve the yield and yield components of crops (Davis, 1983; Fox \& Guerinot, 1998; Ekhtiari et al., 2013). Normally fertilization carried out in soil but in this condition very less amount of nutrient reached to the plant system and remaining amount waste through leaching in soil, it also cause land and water pollution. Foliar fertilization is better option to avoid leaching and in this quick translocation of nutrients carried out in different parts of the plant system (Neumann. 1982). According to Ghasemian et al, (2010) micronutrient spray can enhance resistance against the environmental stress. Geographical region Iran is characterized by arid climatic conditions with high $\mathrm{pH}$ and mean temperature, here plants mostly affected by different abiotic stresses.

In this condition drought stress is the main limiting abiotic factor for crop production and decline the efficient use of dry and semi dry lands. Furthermore, these water stress conditions also severely affect the absorption of micronutrients by plants. Water deficient conditions affect the water potential and turgor pressure of the cells and this can disturbs the normal plant physiological mechanisms (Hsiao, 1973). These changes induced various effects on growth and yield parameters of the crops (Reisdorph \& Koster, 1999). Many studies showed inhibitory effects of drought stress on different plant properties, such as grain yield in maize (Ebrahimian \& Bybordi, 2011); growth and productivity in sunflower, fresh and dry weights in shoot and flowers of marigold (Tagetes erecta L.) and Asian red sage (Asrar \& Elhindi, 2011; Liu et al., 2011) and yield reduction due to limited growth in bread wheat (Abbas et al., 2009). In soybean, biological nitrogen fixation carried out by bacterium Bradyrhizobium sps., it was reported that drought condition adversely affect the biological nitrogen fixation in this crop.

Low soil fertility and limited availability of macro and micro nutrients are the most important constraints under drought conditions. Diagnosis and development of new strategies are required which can help in inducing drought tolerance or reduced the determinable effect of drought on crop, these techniques will also help in the full utilization of the available resources and convert semi-arid land to arable regions (Bruce et al., 2002). Role of trace elements in crops production under drought stress conditions have been less studied by researchers. The aim of the present study was to investigate the response of soybean in term of yield, yield components, seed oil and protein yield to foliar spray of micronutrient (Fe and $\mathrm{Mo}$ ) under drought condition.

\section{Materials and Methods}

\subsection{Study area and Experimental setup}

In order to investigate the effects of micronutrient spray on yield parameters of soybean under drought stress condition, present study was conducted at research farm of Sari Agricultural Sciences and Natural Resources University during the cropping season of 2014. Each experimental plot had 5 meters long and 3 meters $(3 \mathrm{~m} \times 5 \mathrm{~m})$ wide and 6 ridges spaced $50 \mathrm{~cm}$ apart. Soil samples were collected and its physicochemical properties were analyzed in soil science laboratory, Department of soil science, Sari Agricultural sciences and natural Resources University. All the physicochemical properties were analyzed by the method described by Blakemore et al. (1987).

Table 1 Physicochemical and mechanical properties of the experimental area soil.

\begin{tabular}{|lc|}
\hline Depth & $0-30 \mathrm{~cm}$ \\
\hline Texture & Clay silt \\
\hline $\mathrm{EC}_{\mathrm{dS} / \mathrm{m}}$ & 1.4 \\
\hline $\mathrm{pH}$ & 7.5 \\
\hline T.N.V\% & 19.3 \\
\hline $\mathrm{O} . \mathrm{C} \%$ & 3.48 \\
\hline $\mathrm{P}_{\mathrm{ppm}}$ & 12.3 \\
\hline $\mathrm{K}_{\mathrm{ppm}}$ & 367.3 \\
\hline $\mathrm{N}(\%)$ & 0.251 \\
\hline
\end{tabular}

Uniform healthy soybean seeds ( 033 cultivar) were purchased from Iran's Oilseed Research and Development Company Deputy of Sari, Iran. Selected seeds were used for hand sowing in the month of June, 2014 after removing the trashes and impurities. The experiment was laid out in factorial arrangement based on completely randomized block design with three blocks. Two irrigation regimes were used viz irrigation after $65 \mathrm{~mm}$ (as normal irrigation) and $130 \mathrm{~mm}$ (as water deficit) evaporation from Class A pan along with the simultaneous application of spray fertilization of the selected micronutrient either singly or in combination (water as control, $\mathrm{Fe}, \mathrm{Mo}$ and $\mathrm{Fe}+\mathrm{Mo}$ ). For this purpose $\mathrm{FeSO}_{4}$ and (NH4)6Mo7O24 (Merck, Darmstadt, Germany) were used as $\mathrm{Fe}$ (400 ppm) and Mo (4 ppm) spray treatment, respectively. 
The foliar spray of the selected micronutrient was carried out for three times viz. at the start of stem elongation, flower buds formation and pod set stage (according to the drought stress treatment). Urea and ammonium phosphate were applied as nitrogen and phosphate sources at $150 \mathrm{~kg} / \mathrm{ha}^{-1}$ and $100 \mathrm{~kg} \mathrm{ha}^{-1}$, respectively.

The plots were irrigated by tape irrigation method and the applied water amounts were controlled by water meters and the following equation:

$$
d=(F C-\theta) D / 100
$$

Where, $\mathrm{FC}_{\%}=$ field capacity ; $\theta_{\%}=$ soil moisture content; $\mathrm{D}_{\mathrm{cm}}=$ soil depth; $\mathrm{d}_{\mathrm{cm}}=$ irrigation water depth. Soil moisture content was determined by oven drying method (ASTM D2216-10, 2010).

During foliar application, the plots were surrounded by polyethylene to avoid the drift of solutions. Soybean was manually harvested completely from each plot $\left(15 \mathrm{~m}^{2}\right)$ at full physiological maturity of pods $(80-90 \%$ dry weight). Total grain yields after drying in oven $\left(65^{\circ} \mathrm{C}\right.$ for $\left.72 \mathrm{~h}\right)$ were adjusted to $12 \%$ moisture content. Harvest index (HI) by dividing the total grain yield on total biomass was calculated:

$$
\mathrm{HI}=(\mathrm{GY} / \mathrm{BM}) \times 100 \%
$$

Where, $\mathrm{GY}=$ grain yield and $\mathrm{BM}=$ biomass

\subsection{Estimation of total protein content of soybean seeds}

Estimation of total protein content was based on the total nitrogen contents. Nitrogen content of soybean seeds was measured by Total Kjeldahl Nitrogen (TKN) method as mentioned by Isaac \& Johnson (1976) (Kjeltec Auto1030 Analyzer, Foss Tecator AB, Hoganas, Sweden). For nitrogen determination the pure seeds were dried (Fan Azma Gostar, 24060, Iran) for $72 \mathrm{~h}$ in oven. Total reduced nitrogen was determined by using a micro Kjeldahl procedure with sulfuric acid, digestion catalyst and conversion of organic nitrogen to ammonium form according to the Total Kjeldahl Nitrogen
(TKN) method. Nitrogen content is then multiplied by a factor to arrive at protein content. The average nitrogen $(\mathrm{N})$ content of proteins that found by the above method led to use of the calculation N $\times$ convert factor (5.71) (King-Brink \& Sebranek, 1993).

\subsection{Estimation of Total seed oil content}

Total oil content of soybean seeds was determined by using the soxhlet device; the pure seeds of each treatment were dried and weighted before insert into the device. The chloroform was used as solvent, it is a popular solvent seed oil extraction, particularly for lipids of intermediate polarity and when mixed with methanol it becomes a general extraction solvent. So the dried and powdered seed samples were inserted into the soxhlet device and the extraction was completed by evaporating the solvent.

\subsection{Statistical analysis}

Analysis of variance was performed for studied traits by using the general linear model (PROC GLM) procedure in Statistical Analysis System (SAS) and the mean comparisons were evaluated based on Least Significant Differences (LSD).

\section{Results and Discussion}

Drought stress and micronutrient sprays were significantly affected all studied soybean parameters. Also, the interactions were statistically significant among studied traits with the exception of seed number/pod (table 2).

\subsection{Pod number/ plant}

Number of pods per plant is an important growth characteristic in soybean and could be helpful in determining the final plant performance during the growing period (Ohashi \& Nakayama, 2009). During the growth stage, plants were highly affected by water availability and micronutrient application which directly become visible at pods initiation and forming (table 3). Water deficits plots produced a lower number of pods/plant.

\begin{tabular}{|c|c|c|c|c|c|c|c|}
\hline S.O.V & $\overline{\text { d.f }}$ & $\begin{array}{c}\text { Pod number/ } \\
\text { plant }\end{array}$ & $\begin{array}{c}\text { Seed number/ } \\
\text { plant }\end{array}$ & $\begin{array}{l}1000 \text { grain } \\
\text { weight }(\mathrm{g})\end{array}$ & $\begin{array}{l}\text { Seed yield } \\
\left(\mathrm{kg} \mathrm{ha}^{-1}\right)\end{array}$ & $\begin{array}{l}\text { Protein yield } \\
\left(\mathrm{kg} \mathrm{ha}^{-1}\right)\end{array}$ & $\begin{array}{l}\text { Oil yield } \\
\left(\mathrm{kg} \mathrm{ha}^{-1}\right)\end{array}$ \\
\hline Block & 2 & $* *$ & $* *$ & ns & $* *$ & $* *$ & $* *$ \\
\hline W.S. (A) & 1 & $* *$ & $* *$ & $*$ & $* *$ & $* *$ & $* *$ \\
\hline M.S. (B) & 3 & $* *$ & $* *$ & ns & $* *$ & $* *$ & $* *$ \\
\hline $\mathrm{A} \times \mathrm{B}$ & 3 & ns & $* *$ & $* *$ & $*$ & $* *$ & $* *$ \\
\hline Error & 14 & 2.46 & 33.78 & 0.16 & 27099.61 & 5391.83 & 795.33 \\
\hline Total & 23 & & & & & & \\
\hline $\mathrm{CV}$ & & 3.34 & 5.27 & 0.39 & 5.28 & 5.57 & 5.49 \\
\hline
\end{tabular}

Table 2 ANOVA for soybean parameters in response to different micronutrient spray under two irrigation regimes.

Whereas W.S. - Water stress condition; MS- Micronutrient Spray, **;* and ns indicated significant difference at 0.01 and 0.05 probability level and non significant respectively 
Table 3 Means of main effects of drought stress and micronutrient spray on pod numbers.

\begin{tabular}{|lll|}
\hline \multirow{2}{*}{ Treatments } & & Pod number/ plant \\
& Normal & $54.57^{\mathrm{a}}$ \\
\cline { 2 - 3 } & Stress & $39.12^{\mathrm{b}}$ \\
\hline Micronutrient spray & Control & $40.86^{\mathrm{c}}$ \\
\cline { 2 - 3 } & Fe & $42.36^{\mathrm{c}}$ \\
\cline { 2 - 3 } & Mo & $50.35^{\mathrm{b}}$ \\
\cline { 2 - 3 } & Fe + Mo & $53.81^{\mathrm{a}}$ \\
\hline
\end{tabular}

Data with the same letters are not significantly different according to LSD (0.05) probability levels.

This could be explained by a reduction in flower production and by an increase in flower abortion (Ekhtiari et al., 2013). According to the results drought stress severely impressed the number of pods so that the plants which were exposed to water limitation showed highly reduction in term of pod numbers compared to normal condition (more than $28 \%$ reduction). Throughout the different spray of microelements the maximum positive effects on pod numbers was reported from $\mathrm{Fe}+\mathrm{Mo}$ spray treatment (with 53.81 pods/plant) (table 3 ).

Translocation of assimilates from the source leaf to the pods in soybean plant depends on many factors, such as deficiency in water supply and photosynthetic rate (Chen et al., 1993; Ohashi et al., 2000; Nobuyasu et al., 2003). According to Ohashi et al. (2009) drought stress reduced the plant dry weight by decrease pod dry matter accumulation, also they found that, stress conditions reduced the rate of photosynthesis significantly, but these conditions induced greater partitioning of assimilates from the leaf compared to the well water condition. However, these assimilates did not move to the reproductive parts and accumulated in the vegetative structures, mostly in the stem. Findings of present study are in agreement with the Ekhtiari et al. (2013) who suggested that water deficit showed highly inhibition in soybean seed yield. Furthermore, Ohashi et al.(2009) reported different responses of pod thickness and dry matter to drought stress during the grain filling stage in soybean plants. Kaiser et al. (2005) suggested the significant effect of micronutrient such as Mo especially on soybean production. Low soil fertility and limited availability of macro and micro nutrients are the most important constraints under drought conditions. Various studies suggested the reduction in soybean production due to deficiency of micronutrients especially Fe, Mo and Zn (Kaiser et al., 2005; Khudsar et al., 2008; Caliskan et al., 2008).

\subsection{Seed /plant}

The average number of seeds for each plant is relatively constant in normal condition and almost controlled by genetic factors, but it can be rapidly change under adverse environmental conditions (Ohyam et al., 1992). The importance of seed number in final performance of legumes especially in soybean production was investigated by many authors (Kobraee et al., 2011; Yasari \& Vahedi, 2012; Yadavi et al., 2014; Abdel-Latif \& Haggan, 2014) all of them suggested a positive correlation between seed numbers per plant and the final seed performance. However, the average number of seeds was significantly affected by irrigation and micronutrient levels (table 2). According to the results obtained from mean comparison (fig. 1), the number of seeds per plant in each micronutrient spray treatment was reduced under water deficit (Irrigation after $130 \mathrm{~mm}$ evaporation from pan class A) condition as compared to control. Minimum reduction due to drought stress among above parameter was related to $\mathrm{Fe}+\mathrm{Mo}$ treatment ( $7 \%$ reduction in compare control), in other words, there was no significant difference with the control.

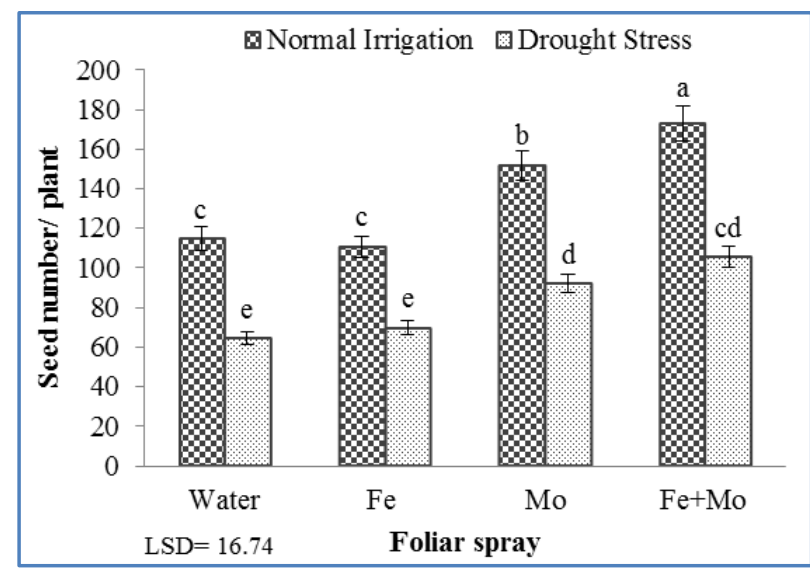

Figure 1 Response of soybean seed numbers to micronutrient spray under different water status 
Water deficiency reduces water potential and turgor pressure in plant which lead to difficulty in performing normal physiological function especially during the reproductive period (Lisar et al., 2012). Also, in present study highest seed numbers per plant was obtained when $\mathrm{Fe}+\mathrm{Mo}$ spray was applied under normal irrigation (more than 173 seeds in each plant) and the lowest was belong to water spray treatment in drought stress condition (less down 65 seeds/plant) (fig. 1). The role of molybdenum in plant growth and seed setting has been well documented before (Arnon \& Stout, 1939; Anderson, 1942; Davies, 1945; Mitchell, 1945; Fido et al., 1977; Chatterjee \& Nautiyal, 2001; Kaiser et al., 2005). Result of study suggested that by using some good strategies such as foliar application of essential micronutrient especially $\mathrm{Mo}+\mathrm{Fe}$ help in normal functioning of specific plant enzymes to participate in reduction and oxidative reactions, it could reduced the damage caused by drought stress in plants particularly in soybean.

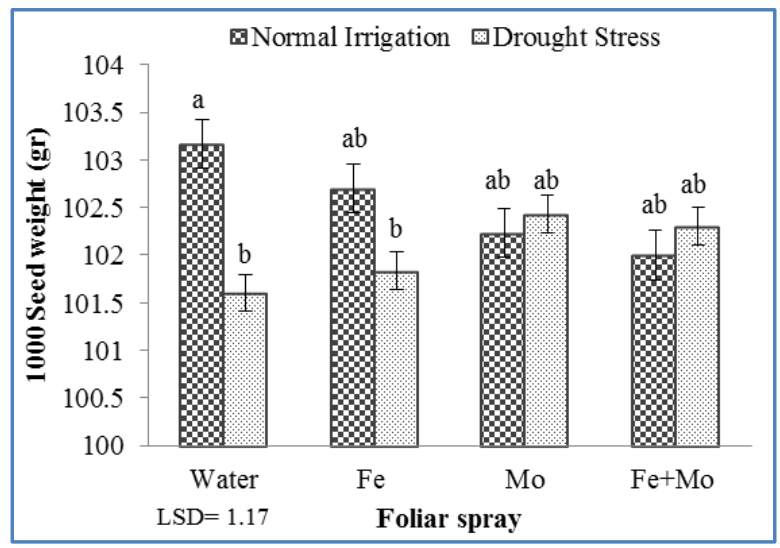

Figure 2 Impact of micronutrient spray under different water status on the weight of 1000 soybean seed.

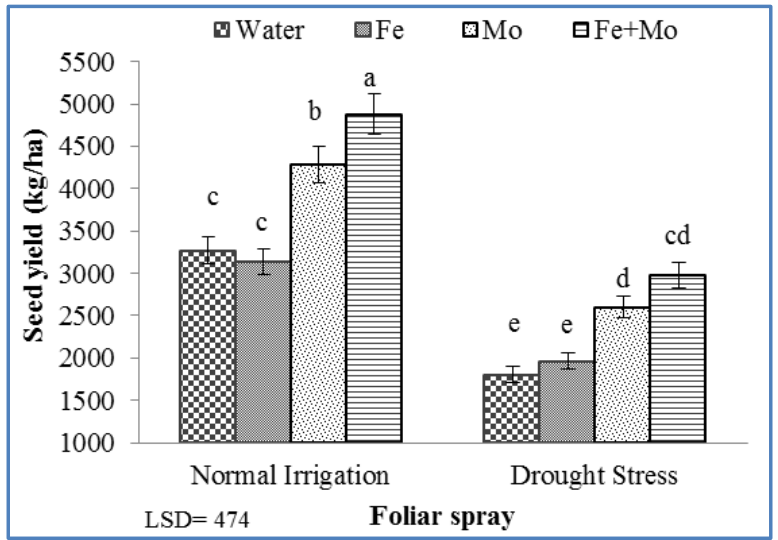

Figure 3 Response of soybean seed yield to micronutrient spray under different water status.

\subsection{Effect of foliar spray on 1000 grain weight}

Weight of 1000 Grain is an important yield contributing factor, which plays an important role in showing the potential of a crop variety. The average weight of 1000 grain was in ranges of 101.6-103.2g and statistically analysis revealed that water limitation significantly affected this parameter, in contrast the micronutrient sprays didn't (table 2). However, the interactions had significant effects on this parameter (fig. 2). According to the mean comparison the highest 1000 grain weights was obtained in control treatment (water spray with stress) with $103 \mathrm{~g}$ but it was not significantly different from the $\mathrm{Fe}+\mathrm{Mo}$ spray treatment (102.3g). Since the high genetically dependence of grain weight to the variety, this factor affected in lower range by drought stress and foliar application of micronutrients compared with other yield properties. It seems that, micronutrient treatments could increase the soybean seed weight under water deficit condition and conversely, under normal irrigation it didn't work. Drought stress occurring during the critical growth stages of soybean (flowering to early pod expansion period) ultimately decreases individual seed weight but spray of micronutrients may rectify this effect (Royo et al., 2000).

\subsection{Seed yield}

Seed yield is a final performance which resulted by integrated effects of many complex morphological and physiological processes occurring throughout the growth and development of a crop. Due to water deficiency seed yield in soybean was reduced if water limitation occurs during the critical growth stage of growth especially at the time of pod set stage. Mean comparisons of seed yield which influenced by drought stress and micronutrient spray are considered in figure 3, it showed higher reduction in seed yield through the stress condition (fig. 3 ). The highest positive effect on final seed yield (with 4885 $\mathrm{kg} \mathrm{h}-1$ ) was related to $\mathrm{Fe}+\mathrm{Mo}$ treatment in normal irrigation which was significantly higher than other treatments (figure 3 ). The deleterious effects of micronutrient deficiency on seed yields and quality have been reported clearly before (Cakmak, 2002; Welch \& Graham, 2004; Kaiser et al., 2005; Malakouti, 2007). Among various abiotic stresses, drought is one of the major environmental constraints limiting crop productivity worldwide (Masoumi et al., 2010; Khamssi et al., 2011; Batlang et al., 2013). About $25 \%$ of the world's agricultural land is affected by drought stress (Jajarmi, 2009).

Various researchers reported the inhibitory effect of the drought stress on the rate of photosynthesis and growth, particularly seed yield of soybean plants severely affected (De Souza et al., 1997; Griffin \& Luo, 1999; Earl, 2002). In the present study the seed yield was limited by water shortage but the micronutrient sprays could partially mitigate these adverse effects (fig. 3), for instance; spray of Fe+Mo could compensated the yield loss due to drought stress and accordingly no significantly difference was observed between mentioned treatment under drought stress and control (water spray) under normal irrigation (figure 3). Drought stress decreases soybean yield by decline in yield components, although there is a differential responses in yield components to changes in environmental conditions. 
According to Whan et al (1991) partitioning and translocation of assimilates is dependent to water availability in soil (Schnyder, 1993; Wardlow \& Wilenbrink, 1994; Mohapatra et al., 2003; ), thus Soybean yield and its components were markedly reduced in non-irrigated plants compared with irrigated plants (Andriani et al., 1991; Frederick et al., 2001; Kerbauy, 2004 ). According to water deficit at early of flowering and pod set increased flower and pod failure (Osborne et al., 2002). Environmental condition during the reproductive phase has a major impact on final yield (Levitt, 1980).

\subsection{Protein yield}

Soybeans had been cultivated widely due to exceptional protein content (contains all 8 essential amino acids), due to the presence of high protein content it is consider as vegetarian meat (Dwevedi \& Kayastha, 2011). Drought stress negatively affected many physiological processes such as photosynthesis; transpiration; accumulation and assimilates allocation (Ohashi et al., 2006). Water status and micronutrient spray indicated high significant effects on protein yield, also the interaction was significant too (table 2). As drought stress by restriction in micro and macro nutrients uptakes cause the huge yield lose in crops(Ohashi et al., 2006) as well as application of some trace elements such Molybdenum can play a great role in uptake the above nutrients (Kaiser et al., 2005). The results from mean comparison (figure 4) showed substantial different between treatments.

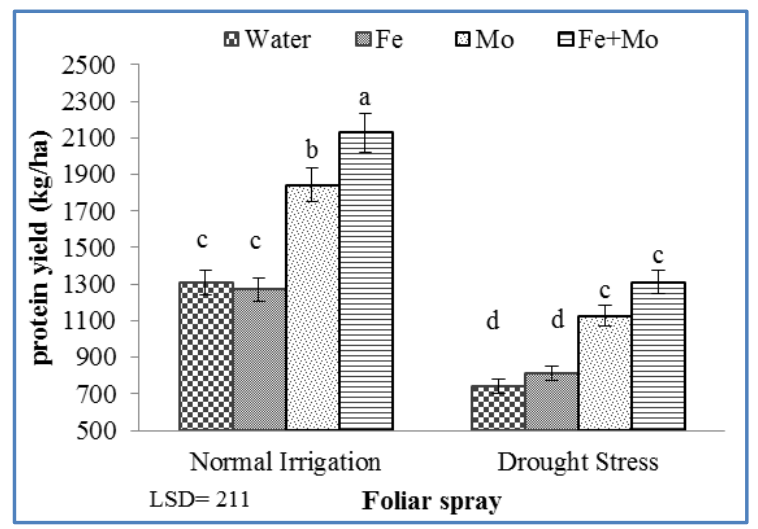

Figure 4 Effect of micronutrient spray under water deficient condition on the yield of soybean seed protein.

Although, there were a huge different between the lowest and highest amount of protein yield, and obtained from water spray through the water stress and $\mathrm{Fe}+\mathrm{Mo}$ spray under normal irrigation treatment respectively. Also there were no significant difference in protein yield between $\mathrm{Fe}+\mathrm{Mo}$ in drought stress and normal irrigation. On the other hand reduction in total protein content has been offset by foliar application of $\mathrm{Fe}+\mathrm{Mo}$ combination. Various studies have been proven the role of molybdenum in biological nitrogen fixation and plant nitrogen metabolism (Mendel \& Haensch, 2002; Williams \& Frausto da Silva, 2002). Furthermore, molybdenum increased the nitrogenase activity and fix higher nitrogen by forming larger root nodules (Parker \& Harris, 1977; Adams, 1997; Vieira et al., 1998). All this ultimately leads to increase nitrogen uptake and transformation to vital metabolites such as proteins (Kaiser et al., 2005).

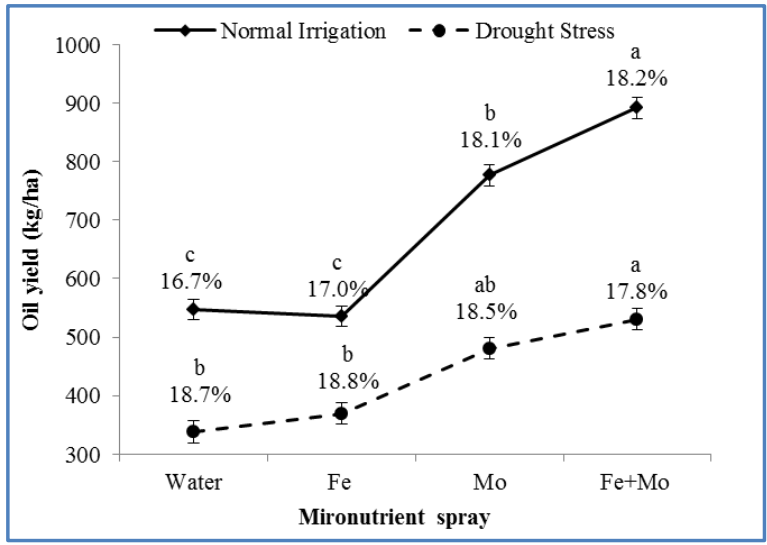

Figure 5 Impact of micronutrient spray under different water status on soybean seed yield (The bar demonstrated the oil percentages)

\subsection{Oil yield}

Like protein, content of seed oil is also a major parameter which determining the nutritional value of soybean, seeds of soybean contains about 20\% oil (Dwevedi \& Kayastha, 2011). In present study the mean comparison of seed oil yield and percentage (fig. 5) indicated that drought conditions have negative impact on the oil yield but the oil percentage increased. Meanwhile unlike to other studied parameters (seed yield and protein content) seed oil percentage reduced (fig. 5). Chung et al. (2003) suggested that soybean seed protein content is negatively correlated with the amount of seed oil percentage. Further, it has been demonstrated that water availability will affect seed oil yield and quality (Ku et al., 2013). Nevertheless the highest positive effect on seed oil yield in both water status treatments was related to Fe+Mo spray application which had dramatically difference by the other micronutrients spray. Dornbos \& Mullen (1992) performed a differential irrigation experiment on soybean cultivars and reported a $4.4 \%$ increase in protein content and $2.6 \%$ decrease in oil content under severe drought stress. Similar type of findings was obtained by Vollmann et al. (2000) when they evaluated the response of soybean cultivars to drought condition. Result of this study confirmed a negative correlation between seed protein and seed oil contents as well as the effect of drought on seed protein and seed oil contents. They suggested that, variations in contents of seed protein and oil were attributed largely to the differential rainfall during the seed filling stage. 


\section{Conclusions}

Findings of the present study well demonstrated the positive effects of micronutrients spray particularly $\mathrm{Fe}+\mathrm{Mo}$ treatment on various growth parameters of soybean plant. Further, it was well reported that seed protein and seed oil were strongly affected by water stress conditions. Seed oil percentage response conversely to drought stress as compare to other parameters but this act couldn't alter the final performance of oil yield. Also high reduction in pod numbers during the reproductive stage due to its sensitivity to water limitation was the main cause of the final yield loses. Overall, when plants like soybean are not supplied with an optimum amount of $\mathrm{Fe}$ and Mo due to environmental limitation, growth inhibition and physiological changes will be appear more quickly, depending on the strength and duration of the imposed stress.

\section{Conflict of Interest}

Authors would hereby like to declare that there is no conflict of interests that could possibly arise.

\section{References}

Abbas G, Khan MQ, Khan MJ, Hussain F, Hussain I (2009) Effect of iron on the growth and yield contributing parameters of wheat (Triticum aestivum L.). The Journal of Animal \& Plant Sciences 19: 135-139.

Abdel-Latif E, Haggan MA (2014) Effect of micronutrients foliar application on yield and quality traits of soybean cultivars. International Journal of Agriculture and Crop Sciences 7: 908-914.

Adams JF (1997) Yield response to molybdenum by field and horticultural crops. In: Gupta UC (Ed.) Molybdenum in agriculture. Cambridge University Press, Cambridge.

Anderson AJ (1942) Molybdenum deficiency on a South Australian ironstone soil. Journal of the Australian Institute of Agricultural Science 8: 73-75.

Andriani JM, Andrade FH, Suero EE, Dardanelli JL (1991) Water deficits during reproductive growth of soybeans. I. Their effect on dry matter accumulation, seed yield and its components. Agronomie 11: 737-746. http://dx.doi.org/10.1051/agro:19910904.

Arnon DI, Stout PR (1939) Molybdenum as an essential element for higher plants. Plant Physiology 14: 599-602.

Asrar AW, Elhindi KM (2011) Alleviation of drought stress of marigold (Tagetes erecta) plants by using arbuscular mycorrhizal fungi. Saudi Journal of Biological Sciences 18: 93-8. DOI:10.1016/j.sjbs.2010.06.007.
ASTM D2216-10 (2010) Standard Test Methods for Laboratory Determination of Water (Moisture) Content of Soil and Rock by Mass, ASTM International, West Conshohocken, PA, DOI: 10.1520/D2216-10.

Batlang U, Baisakh N, Ambavaram MM, Pereira A (2013) Phenotypic and physiological evaluation for drought and salinity stress responses in rice. Methods in Molecular Biology 956:209-225. DOI: 10.1007/978-1-62703-194-3-15.

Blakemore LC, Searle PL, Daly B K (1987). methods for chemical analysis of soils. New Zealand Soil Bureau Scientific Report 80. pp 103.

Bruce WB, Edmeades GO, Barker TC (2002) Molecular and physiological approaches to maize improvement for drought tolerance. Journal of Experimental Botany 53: 13-25. doi: 10.1093/jexbot/53.366.13.

Cakmak I (2002) Plant nutrition research: Priorities to meet human needs for food in sustainable ways. Plant and Soil 247:3-24. doi: 10.1023/A:1021194511492.

Caliskan S, Ozkaya I Caliskan ME, Arslan M (2008) The effects of nitrogen and iron fertilization on growth, yield and fertilizer use efficiency of soybean in a Mediterranean-type soil. Field Crops Research 108:126-132. DOI:10.1016/j.fcr.2008.04.005.

Chatterjee C, Nautiyal N (2001) Molybdenum stress affects viability and vigour of wheat seeds. Journal of Plant Nutrition 24: 1377-1386. DOI: 10.1081/PLN-100106988.

Chen XM, Begonia GB, Alm DM, Hesketh JD (1993) Responses of soybean leaf photosynthesis to $\mathrm{CO} 2$ and drought. Photosynthetica 29:447-454.

Chung J, Babka HL, Graef GL, Staswick PE, Lee DJ, Cregan PB, Shoemaker RC, Specht JE (2003) The seed protein, oil, and yield QTL on soybean linkage group I. Crop Science 43: 1053-1067. doi:10.2135/cropsci2003.1053.

Davies EB (1945) A case of molybdenum deficiency in New Zealand. Nature 156: 392.

Davis FR (1983) Micronutrients and plant nutrition. Journal American Rhododendron Society 37: 1-3.

De Souza PI, Egli DB, Bruening WP (1997) Water stress during seed filling and leaf senescence in soybean. Agronomy Journal 89: 807-812. doi:10.2134/agronj1997.00021962008900050015x. 
Dornbos DL, Mullen RE (1992) Soybean seed protein and oil contents and fatty acid composition adjustments by drought and temperature. Journal of the American Oil Chemists' Society 69: 228-231. DOI: 10.1007/BF02635891.

Dwevedi A, Kayastha AM (2011) Soybean: a Multifaceted Legume with Enormous Economic Capabilities. In: Tzi-Bun N (Ed.), Soybean - Biochemistry, Chemistry and Physiology, InTech Europe University Campus STeP Ri Slavka Krautzeka 83/A 51000 Rijeka, Croatia .

Earl HJ (2002) Stomatal and non-stomatal restrictions to carbon assimilation in soybean (Glycine max) lines differing in water use efficiency. Environmental and Experimental Botany 48:237-246. DOI:10.1016/S0098-8472(02)00041-2.

Ebrahimian E, Bybordi A (2011) Effect of Iron Foliar Fertilization on Growth, Seed and Oil Yield of Sunflower Grown under Different Irrigation Regimes. Middle-East Journal of Scientific Research 9: 621-627.

Ekhtiari S, Kobraee S, Shamsi K (2013) Soybean yield under water deficit conditions. Journal of Biodiversity and Environmental Sciences 3: 46-52.

Fido RJ, Gundry CS, Hewitt EJ, Notton BA (1977) Ultrastructural features of molybdenum deficiency and whiptail of cauliflower leaves: effects of nitrogen source and tungsten substitution for molybdenum. Australian Journal of Plant Physiology 4: 675-689. DOI:10.1071/PP9770675.

Fox TC, Guerinot ML (1998) Molecular biology of cation transport in plant. Plant Molecular Biology 49: 669-696. DOI: 10.1146/annurev.arplant.49.1.669.

Frederick JR, Camp CR, Bauer PJ (2001) Drought stress effects on branch and mainstern seed yield and yield components of determinate soybean. Crop Science 41: 759-63. DOI: $10.2135 /$ cropsci2001.413759x.

Ghasemian V, Ghalavand A, Soroosh zadeh A, Pirzad A (2010) The effect of iron, zinc and manganese on quality and quantity of soybean seed. Journal of Phytology 2: 73-79.

Griffin KL, Luo YQ (1999) Sensitivity and acclimation of Glycine $\max$ (L.) Merr. leaf gas exchange to $\mathrm{CO} 2$ partial pressure. Environmental and Experimental Botany 42:141153. DOI:10.1016/S0098-8472(99)00028-3 .

Hsiao TC (1973) Plant responses to water stress. Annual Review of Plant Physiology 24:519-570. DOI: 10.1146/annurev.pp.24.060173.002511.

Isaac RA, Johnson WC (1976) Determination of total nitrogen in plant tissue, using a block digester. Journal of AOAC International 69: 98-101.
Jajarmi V (2009) Effect of water stress on germination indices in seven wheat cultivar. World Academy of Science, Engineering and Technology 49:105-106. DOI: 10.1.1.192.9597.

Kaiser BN, Gridley K, Brady J, Phillips T, Tyerman SD (2005) The role of molybdenum in agricultural plant production. Annals of Botany 96: 745-754. DOI: 10.1093/aob/mci226. Kerbauy GB (2004) Plant Physiology. Guanabara Koogan S.A, Rio de Janeiro, 452.

Khamssi NN, Golezani KG, Najaphy A, Zehtab S (2011) Evaluation of grain filling rate, effective grain fi lling period and resistance indices under acclimation to gradual water deficit stress in chickpea cultivars. Australian Journal of Crop Science 5:1044-1049.

Khudsar T, Arshi A, Siddiqi TO, Mahmooduzzafar M, Iqbal M (2008) Zinc-Induced Changes in Growth Characters, Foliar Properties, and Zn-Accumulation Capacity of Pigeon Pea at Different Stages of Plant Growth. Journal of Plant Nutrition 31: 281-306. DOI:10.1080/01904160701853894.

King-Brink MA, Sebranek JG (1993) Performance of an automated high temperature combustion-thermal conductivity method for measurement of protein content of food products. Pittsburgh Conference, Atlanta, Georgia March 1993. Abstract 168P.

Kobraee S, Noormohamadi G, Heidarisharifabad H, Darvishkajori F, Delkhosh B (2011) Influence of micronutrient fertilizer on soybean nutrient composition. Indian Journal of Science and Technology 4: 763-769. DOI: 10.17485/ijst/2011/v4i7/30107.

Ku YS, Yeung WKA, Yung YL, Li MW, Wen CQ, Liu X, Lam HM (2013) Drought Stress and Tolerance in Soybean. In: Board J (Ed).A comprehensive survey of international soybean research-genetics, physiology, agronomy and nitrogen relationships. $1^{\text {a }}$ ed. Intech, cap. 10, p. 209- 237.

Levitt J (1980) Responses of plants to environmental stresses, $2^{\text {nd }}$ Edn. Academic Press, New York, Pp. 497.

Lisar SYS, Motafakkerazad R, Hossain MM, Rahman IMM (2012) Water stress in plants: auses, effect and responses. In: Ismail MR (Ed) Water stress. InTech Publishers. InTech Europe University Campus STeP Ri Slavka Krautzeka 83/A 51000 Rijeka, Croatia 1-15.

Liu CJ, Miao YC, Zhang KW (2011) Sequestration and transport of lignin monomeric precursors. Molecules 16:710727. doi:10.3390/molecules 16010710. 
Malakouti MJ (2007) Zinc is a neglected element in the life cycle of plants. A review. Middle Eastern and Russian Journal of Plant Science and Biotechnology 1: 1-12.

Masoumi A, Kafi M, Khazaei H, Davari K (2010) Effect of drought stress on water status, electrolyte leakage and enzymatic antioxidant of Kochia ( Kochia scoparia) under saline condition. Pakistan Journal of Botany 42:3517-3524.

Mendel RR, Haensch R (2002) Molybdoenzymes and molybdenum cofactor in plants. Journal of Experimental Botany 53: 1689-1698. doi:10.1080/07352689991309180.

Mitchell KJ (1945) Preliminary note on the use of ammonium molybdate to control whiptail in cauliflower and broccoli crops. New Zealand Journal of Science and Technology 27: 287-293.

Mohapatra PK, Turner NC, Siddique KHM (2003) Assimilate partitioning in chickpea (Cicer arietinum L.) in drought prone environment. In: Saxena NP (Ed) Management of agricultural drought: agronomy and genetic options. Science Publishers Inc., Enfield, Australia, Pp 173-188.

Neumann PM (1982) Late-season foliar fertilization with macronutrients - Is there a theoretical basis for increased seed yields. Journal of Plant Nutrition 5:1209-1215. DOI: 10.1080/01904168209363054.

Nobuyasu H, Liu S, Adu-Gyamfi JJ, Mohapatra PK, Fujita K (2003) Variation in the export of $13 \mathrm{C}$ and $15 \mathrm{~N}$ from soybean leaf: the effects of nitrogen application and sink removal. Plant and Soil 253:331-339. DOI: 10.1023/A:1024836600725.

Ohashi Y, Nakayama N (2009) Differences in the responses of stem diameter and pod thickness to drought stress during the grain filling stage in soybean plants. Acta Physiologiae Plantarum 31: 271-277. DOI: 10.1007/s11738-008-0229-4.

Ohashi Y, Nakayama N, Saneoka H, Fujita K (2006) Effects of drought stress on photosynthetic gas exchange, chlorophyll fluorescence and stem diameter of soybean plants. Biologia Plantarum 50: 138-141. doi: 10.1007/s10535-005-0089-3.

Ohashi Y, Saneoka H, Fujita K (2000) Effect of water stress on growth, photosynthesis, and photoassimilate translocation in soybean and tropical pasture legume siratro. Soil Sci Plant Nutr. 46:417-425. DOI: 10.1080/00380768.2000.10408795.

Ohyama T, Takahashi Y, Chinushi T, Nakano T (1992) Evaluation of $\mathrm{N} 2$ fixation activity and nitrogen absorption rate in field grown soybean plants by simple relative ureide method. Agriculture and Horticulture 67: 1157-1164.

Osborne SL, Shepers J, Fransis DD, Schlemmer MR (2002) Use of spectral radiance to in season biomass and grain yield in nitrogen water- stressed corn. Crop Science. 42: 165-171. DOI: $10.2135 /$ cropsci2002.0165.
Parker MB, Harris HB (1977) Yield and leaf nitrogen of nodulating and nonnodulating soybeans as affected by nitrogen and molybdenum. Agronomy Journal 69: 551-554. doi:10.2134/agronj1977.00021962006900040007x.

Reisdorph NA, Koster KI (1999) Progressive loss of desiccation tolerance in germinating pea (Pisum sativum) seeds. Physiologia Plantarum 105: 266-271. DOI: 10.1034/j.1399-3054.1999.105211.x.

Royo C, Abaza M, Blanco R, Garcia del Moral LF (2000) Triticale grain growth and morphometry as affected by drought stress, late sowing, and simulated drought stress. Australian Journal Plant Physiology 27: 1051-1059. DOI:10.1071/PP99113.

Schnyder H (1993) The role of carbohydrate storage and redistribution in the source-sink relations of wheat and barley during grain filling - a review. New Phytologist 123: 233-245. DOI: 10.1111/j.1469-8137.1993.tb03731.x.

Turner LB (1991) The effect of water stress on vegetative growth of white clover (Trifolium repens L.): Comparison of long-term water deficit and short-term developing water stress. Journal of Experimental Botany 42: 311-316. DOI: 10.1093/jxb/42.3.311.

Vieira RF, Cardoso EJBN, Vieira C, Cassini STA (1998) Foliar application of molybdenum in common beans. I. Nitrogenase and reductase activities in a soil of high fertility. Journal of Plant Nutrition 21: 169-180. DOI: 10.1080/01904169809365391.

Vollmann J, Fritz CN, Wagentristl H, Ruckenbauer P (2000) Environmental and genetic variation of soybean seed protein content under Central European growing conditions. Journal of the Science of Food and Agriculture 80: 1300-1306. DOI: 10.1002/1097-0010(200007)80:9<1300::AID-

JSFA640>3.0.CO;2-I.

Wardlaw IF, Willenbrink J (1994) Carbohydrate storage and mobilization by the culm of wheat between heading and grain maturity: the relation to sucrose synthase and sucrosephosphate synthase. Australian Journal of Plant Physiology 21: 255-271.

Welch RM, Graham RD (2004) Breeding for micronutrients in staple food crops from a human nutrition perspective. Journal of Experimental Botany 55:353-364. DOI: 10.1093/jxb/erh064.

Whan BR, Anderson WK, Gilmour RF, Regan KL, Turner NC (1991) A role of physiology in breeding for improved wheat yield under drought stress. In: Acevedo E, Conesa AP, Monne veux P, Srivastava JP (Eds), Physiology - breeding of winter cereals for stressed Mediterranean environments held at RA, Paris, France, Pp: 179-194. 
Williams RJP, Frausto da Silva JJR (2002) The involvement of molybdenum in life. Biochemical and Biophysical Research Communications 292: 293-299. doi:10.1006/bbrc.2002.6518.

Yadavi A, Aboueshaghi RS, Dehnavi MM, balouchi H (2014) Effect of micronutrients foliar application on grain qualitative characteristics and some physiological traits of bean
(Phaseolus vulgaris L.) under drought stress. Indian journal of fundamental and applied life sciences 4: 124-131.

Yasari E, Vahedi A (2012) Micronutrients Impact on Soybean (Glycine $\max$ (Merrill) Qualitative and Quantitative Traits. International Journal of Biology 4: 112-118. http://dx.doi.org/10.5539/ijb.v4n2p112. 